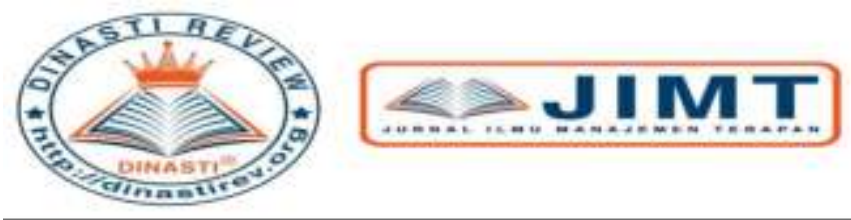

+62 878-9658-6407

087896586407

https://dinastirev.org/JIMT editor@dinastirev.org

\title{
ANALISIS SWOT PADA PT. MEDIA PAJAK INDONESIA (TAXMEDIA)
}

\author{
Widya Aipama \\ Universitas Mercu Buana, Jakarta, Indonesia
}

\begin{tabular}{|c|l|}
\hline $\begin{array}{c}\text { ARTICLE INFORMATION } \\
\text { Received: 02/12/2019 } \\
\text { Revised: 11/12/2019 } \\
\text { Issued: 31/12/2019 } \\
\text { (filled in by Editor) }\end{array}$ & $\begin{array}{l}\text { Abstrak: PT Media Pajak Indonesia (Taxmedia) adalah } \\
\text { perusahaan yang bergerak dalam bidang jasa konsultan } \\
\text { pajak. Tujuan dari penelitian ini adalah untuk } \\
\text { menganalisis kondisi internal dan eksternal perusahaan } \\
\text { guna memperoleh keunggulan bersaing bagi perusahaan. } \\
\text { Metode penelitian yang digunakan dalam penelitian ini } \\
\text { adalah metode analisis swot Teknik pengumpulan data } \\
\text { menggunakan wawancara yang dilakukan terhadap } \\
\text { pihak-pihak terkait di dalam perusahaan. Data-data yang } \\
\text { telah diperoleh tersebut dianalisis menggunakan } \\
\text { deskriptif analisis swot. Srategy menunjukkan alternatif } \\
\text { yang dapat diterapkan perusahaan adalah strategi } \\
\text { marketing, operasional dan finance. Hasil akhir } \\
\text { penelitian ini menyimpulkan bahwa rekomendasi atau } \\
\text { usulan strategi bisnis yang tepat bagi perusahaan } \\
\text { didapat berdasarkan hasil perumusan analisis swot. }\end{array}$ \\
Emaidyaaipama@gmail.com \\
Kata Kunci: Manajemen Strategi, Analisis SWOT
\end{tabular}

\section{PENDAHULUAN}

Dalam beberapa tahun belakangan ini hingga sekarang dunia bisnis telah memasuki era revolusi informasi yang ditandai dengan perubahan lingkungan dengan karakteristik yang jauh berbeda dari era-era sebelumnya. Dalam era revolusi industri, keunggulan daya saing suatu entitas usaha ditentukan oleh efisiensi dalam alokasi sumber daya atau asset berwujud (tangible resources/assets) yang mudah dijabarkan dalam dimensi keuangan. Sebaliknya, dalam era revolusi informasi, keunggulan daya saing suatu entitas usaha sangat tergantung pada kemampuannya untuk memobilisasi dan mengeksploitasi sumber daya atau asset tak berwujud (intangible resources/assets) yang tidak mudah dijabarkan dalam dimensi keuangan (Prakarsa dalam Yuwono, 2007).

Menurut Porter (1996), mengelola strategi adalah berbeda dengan mengelola operasi. Tetapi keduanya sangat penting, dan perlu diintegrasikan. Strategi visioner yang tidak dikaitkan dengan keunggulan proses operasi dan tata kelola (governance) tidak akan dapat diterapkan. Sebaliknya, keunggulan operasi mungkin bisa menurunkan biaya, memperbaiki mutu dan mengurangi jumlah proses dan waktu tunggu, tetapi tanpa visi dan panduan dari strategi, perusahaan tidak mungkin menikmati kesuksesan yang berkesinambungan hanya dengan perbaikan operasi semata (Kaplan \& Norton, 2008). Perkembangan kondisi eksternal yang dinamis dan situasi internal dalam perusahaan yang ingin terus bergerak maju telah 
menuntut perusahaan untuk merumuskan strategi bisnisnya dengan baik dan bisa memandu implementasinya sehingga berhasil mewujudkan visi dan misi yang telah dicanangkan.

Di tengah pergerakan bisnis barang dan jasa, data menunjukkan bahwa pertumbuhan bisnis jasa telah mengalami peningkatan yang tinggi, seperti yang dipublikasikan oleh Biro Pusat Statistik (2018) bahwa laju pertumbuhan Produk Domestik Bruto (PDB) Indonesia menurut lapangan usaha dari sektor jasa mengalami kenaikan sebesar 9,08\% dari triwulan I sampai dengan triwulan IV tahun 2018 jika dibandingkan dengan triwulan yang sama pada tahun 2017. Dari beragamnya bisnis jasa yang ada maka salah satu yang terpenting adalah bisnis jasa konsultan pajak. Hal ini di sebabkan jasa konsultan pajak sangat berperan dalam pemasukan negara.

PT. Media Pajak Indoensia (Taxmedia) merupakan kumpulan konsultan pajak yang bersertifikat dan terdaftar di Direktorat Jenderal Perpajakan. Kumpulan konsultan membentuk usaha konsultan pajak, dengan berbekal pengalaman lebih dari 10 tahun dibidang jasa perpajakan dan keuangan. Taxmedi memiliki visi menjadi salah satu bisnis konsultan terbaik di Indonesia. Taxmedia berkomitmen untuk membantu setiap wajib pajak orang pribadi dan badan usaha dalam memberikan saran terbaik untuk setiap keputusan bisnis yang berhubungan dengan pemenuhan kewajiban perpajakan dan akuntansi. Selain itu juga perusahaan ini berkomitmen, dengan menjaga integritas dan profesionalitas, tim konsultan berusaha memberikan layanan terbaik, mudah, cepat, dan akurat bagi setiap klien.

Jasa yang ditawarkan di Taxmedia adalah 1. Jasa Perpajakan ( tax compliance, tax planning, transfer pricing dokumen, pemeriksaan pajak dan pendampingan sengketa perpajakan), 2. Jasa Accounting ( jasa pembukuan, pembuatan laporan keuangan) 3. Edukasi ( workshop, training dan seminar perpajakan). Hal inilah yang melatar belakangi saya menulis artikel dengan judul Analisis Swot Pada PT. Media Pajak Indonesia ( Taxmedia ).

\section{KAJIAN PUSTAKA}

Dewasa ini, setiap manager semua jenis organisasi senantiasa dituntut untuk berfikir secara strategis mengenai posisi dan kemampuan kompetitif organisasinya dan pengaruh perkembangan lingkungan luar terhadap organisasi. Manager atau pemimpin organisasi harus memahami betul-betul bisnis dan tugasnya, sehingga pada saatnya akan mengetahui strategi yang harus dibuat dalam menghadapi suatu perubahan atau situasi tertentu. Strategi adalah suatu alat untuk mencapai tujuan jangka panjang (David, 2009: 15). Dalam perumusan strategi, faktor-faktor yang harus dipertimbangkan adalah kondisi internal (kekuatan dan kelemahan) dan kondisi eksternal (peluang dan ancaman) yang dihadapi oleh perusahaan. Hansen dan Smith (David, 2006: 225) pernah menjelaskan bahwa perencanaan strategi melibatkan "pilihan yang membahayakan sumber daya" dan "trade-off yang mengorbankan peluang", artinya dalam menetapkan strategi menanggung resiko yang besar sehingga membutuhkan keputusan manajemen tingkat atas dan prioritas harus ditetapkan.

\section{Manajemen Strategis}

Manajemen strategis adalah suatu ren- cana yang disusun dan dikelola deng- an memperhitungkan berbagai sisi de- ngan tujuan agar pengaruh rencana tersebut bisa memberikan dampak positif bagi organisasi tersebut secara ja- ngka panjang (Fahmi, 2014:2). 
Strategi

Definisi strategi menurut Chandler dalam Rangkuti (2014:4) yaitu adalah tujuan jangka panjang dari suatu per- usahaan, serta pendayagunaan dan alo- kasi semua sumber daya yang pe-nting untuk mencapai tujuan tersebut.

\section{Perencanaan Strategis}

Perencanaan strategis merupakan proses analisis, perumusan dan evaluasi strategistrategi (Rangkuti, 2014:2). Kegiatannya meliputi pengamatan se- cara hati-hati persaingan, peraturan, ti- ngkat inflasi, siklus bisnis, keinginan dan harapan konsumen, serta faktorfaktor lain yang dapat mengidentifika- si peluang serta ancaman.

Menurut Rangkuti (1998: 3), suatu perusahaan dapat mengembangkan strategi untuk mengatasi ancaman eksternal dan merebut peluang yang ada. Proses analisis, perumusan dan evaluasi strategi-strategi itu disebut perencanaan strategis. Tujuan utama perencanaan strategis adalah agar perusahaan dapat melihat secara obyektif kondisi-kondisi internal dan eksternal, sehingga perusahaan dapat mengantisipasi perubahan lingkungan eksternal.

\section{SWOT}

Menurut Philip Kotler, pengertian analisis SWOT adalah evaluasi terhadap semua kekuatan, kelemahan, peluang, dan ancaman, yang terdapat pada individu atau organisasi (Kotler, 2015).

Prosedur yang ditempuh dalam penyusunan Rencana Strategis ini meliputi: metode pengumpulan data, analisis lingkungan eksternal (peluang dan ancaman) dan analisis lingkungan internal (kekuatan dan kelemahan). Analisis lingkungan eksternal (peluang dan ancaman) menurut Hit (2001: 52-83), menjabarkan bahwa. Pertama, peluang (opportunities) adalah kondisi-kondisi dalam lingkungan umum yang dapat membantu organisasi mencapai daya saingnya. Kedua, ancaman (threats) adalah kondisi-kondisi dalam lingkungan umum yang dapat mengganggu usaha organisasi dalam mencapai daya saing strategis. Tujuan audit eksternal adalah untuk mengembangkan daftar terbatas peluang yang dapat dimanfaatkan oleh organisasi dan ancaman yang harus dihindari. Komponen analisis eksternal terdiri dari: scanning, mengidentifikasi petunjuk awal dari perubahan dan kecenderungan lingkungan; monitoring, mendeteksi arti melalui observasi terus menerus atas perubahan dan kecenderungan lingkungan; forecasting, mengembangkan proyeksi atas hasil yang diantisipasi berdasarkan perubahan dan kecenderugan yang dimonitor; assessing, menentukan waktu dan pentingnya perubahan serta kecenderungan lingkungan untuk strategi organisasi dan manajemennya. Selanjutnya menurut Hit (2001: 99-129), analisis lingkungan internal (kekuatan dan kelemahan), terdiri dari: kekuatan (strengths) yakni sumber daya, ketrampilan atau keunggulan- keunggulan lain relatif terhadap pesaing dan kebutuhan masyarakat yang dilayani atau ingin dilayani oleh organisasi; lelemahan (weakness) yakni keterbatasan atau kekurangan dalam sumber daya, ketrampilan dan kapabilitas yang secara serius menghambat kinerja efektif organisasi. Kekuatan (distinctive competencies) adalah kekuatan suatu perusahaan yang tidak dapat dengan mudah ditandingi atau ditiru oleh pesaing, kemampuan yang berharga (valuable capabilities), kemampuan yang langka (rare capabilities), kemampuan yang tak dapat ditiru dengan sempurna (imperfectly imitable capabilities), kemampuan yang tak dapat diganti (nonsubstituable capabilities). 


\section{METODE PENELITIAN}

Metode penelitian yang digunakan adalah metode deskriptif kualitatif, yaitu metode yang bertujuan membantu memecahkan masalah yang bertujuan membantu memecahkan masalah yang terjadi pada masa sekarang serta berpusat pada masalah yang actual. Metode deskriptif menggambarkan sifat sesuatu yang tengah berlangsung pada saat riset dilakukan dan memeriksa sebab-sebab dari suatu gejala tertentu (Taver dalam Sugiono, 2000: 22). Untuk merumuskan atau memformulasikan strategi, dengan menggunakan analisis swot.

\section{HASIL DAN PEMBAHASAN}

\section{Strengths}

1. Konsultan Pajak yang memiliki sertifikat/lisensi dan terdaftar di Direktorat Jendral Perpajakan

2. Sumber daya manusia yang profesional dan berpengalaman di bidang akuntansi dan perpajakan

3. Pelayanan yang cepat dan akurat

4. Menjaga kerahasiaan data klien

5. Lokasi yang strategis di Jakarta Barat

6. Fee negotiable

\section{Weaknesss}

1. Marketing yang kurang maksimal

2. Jasa yang disediakan masih sedikit

3. Dana yang masih terbatas untuk membesarkan kapasitas

4. Belum memiliki sumber daya manusia dari warga negara asing

\section{Opportunities}

1. Banyak wajib pajak yang belum paham dengan peraturan perpajakan yang berlaku

2. Peraturan yang sering berubah dan dinamis

3. Jumlah wajib pajak yang lebih banyak dari konsultan pajak yang tersebar di Indonesia

4. Banyaknya penanam modal asing yang belum paham perpajakan Indonesia

5. Banyak perusahaan yang tidak memiliki sdm yang fokus menangani perpajakan

\section{Threats}

1. Pesaing yang lebih lama berdiriSDM yang masih kurang

2. Perilaku wajib pajak yang menyimpang dari peraturan

3. Networking belum banyak

4. Perkembangan tekhnologi yang menyebabkan bisnis ini terancam digantikannya semua pekerjaan yg administratif.

\section{KESIMPULA DAN SARAN}

\section{Kesimpulan}

1. Taxmedia memiliki kekuatan yaitu memiliki sertifikat/lisensi dan terdaftar di Direktorat Jendral Perpajakan, memiliki sumber daya manusia yang profesional dan berpengalaman di bidang akuntansi dan perpajakan, pelayanan yang cepat dan akurat, menjaga kerahasiaan data klien, lokasi yang strategis di Jakarta Barat dan fee bisa di negosiasikan sehingga harga lebih terjangkau. 
2. Taxmedia memiliki kelemahan yaitu marketing yang kurang maksimal, jasa yang disediakan masih sedikit, dana yang masih terbatas untuk membesarkan kapasitas, dan belum memiliki sumber daya manusia dari warga negara asing.

3. Peluang yang ada untuk Taxmedia adalah banyak wajib pajak yang belum paham dengan peraturan perpajakan yang berlaku, peraturan yang sering berubah dan dinamis, jumlah wajib pajak yang lebih banyak dari konsultan pajak yang tersebar di Indonesia, banyaknya penanam modal asing yang belum paham perpajakan Indonesia, dan banyak perusahaan yang tidak memiliki sdm yang fokus menangani perpajakan.

4. Ancaman yang ada adalah Pesaing yang lebih lama berdiri, SDM yang masih kurang banyak, perilaku wajib pajak yang menyimpang dari peraturan, networking belum sebanyak pesaing besar, dan perkembangan tekhnologi yang menyebabkan bisnis ini terancam digantikannya semua pekerjaan yg bersifat administratif.

\section{Saran}

1. Taxmedia perlu menerapkan analisis swot dalam memberikan pelayanan yang terbaik kepada para wajib pajak/ klien dan mencapai keunggulan dalam memberikan jasa konsultasi pajak terbaik di Indonesia.

2. Dalam segi SDM, strategi Taxmedia membentuk komunitas dan akademi sudah tepat karena bisa mendapatkan sdm yang unggul dan terlatih sesuai dengan visi misi Taxmedia.

3. Dalam segi Marketing, Taxmedia perlu membentuk divisi marketing supaya lebih fokus memasarkan jasa yang tersedia. Selain itu perlu merekrut sdm wna supaya bisa menjangkau wajib pajak dari negara lain yang mendirikan usaha di Indonesia.

4. Dalam segi Operasional, Taxmedia perlu memperbanyak jasa yang disediakan supaya memperbanyak klien dan tentunya dalam upaya membantu para wajib pajak dalam membayar pajak.

5. Dalam segi Finance, untuk para pemegang saham Taxmedia perlu mengumpulkan terlebih dahulu fee dari klien untuk memperbesar dan mengembangkan kapasitas Taxmedia.

\section{DAFTAR RUJUKAN}

Achmad Kuncoro, Engkos. 2008. Analisi Perumusan Strategi Pada PT. Samudera Nusantara Logistindo. Universitas Bina Nusantara. Jakarta.

Hapzi Ali, 2019. Modul Manajemen Strategic, UMB Jakarta. Kotler, P., \& Keller, K. L. (2015). Manajemen Pemasaran Jilid 1. Jakarta: Erlangga. Pearce,

John, dan B. Robinson. (1997). Manajemen strategi Formulasi, Implementasi, dan Pengendalian.Jakarta: Binarupa Aksara.

Ramadhan, Riszky. Nourlette, Shinta Wahyu Hati. 2016. Penentuan Strategi dengan Pendekatan Analisis Swot pada PT. Media Pajak Indonesia ( Taxmedia) dalam menghadapi persaingan Bisnis. Politeknik Negeri Batam. Batam. 